\title{
GCU
}

Glasgow Caledonian

University

University for the Common Good

\section{The ethics of and the appropriate legislation concerning killing people and letting them die: a response to Merkel}

McLachlan, Hugh V.

Published in:

Journal of Medical Ethics

DOI:

10.1136/medethics-2016-104027

Publication date:

2017

Document Version

Author accepted manuscript

Link to publication in ResearchOnline

Citation for published version (Harvard):

McLachlan, HV 2017, 'The ethics of and the appropriate legislation concerning killing people and letting them die: a response to Merkel', Journal of Medical Ethics, vol. 43, no. 7, pp. 482-484.

https://doi.org/10.1136/medethics-2016-104027

\section{General rights}

Copyright and moral rights for the publications made accessible in the public portal are retained by the authors and/or other copyright owners and it is a condition of accessing publications that users recognise and abide by the legal requirements associated with these rights.

Take down policy

If you believe that this document breaches copyright please view our takedown policy at https://edshare.gcu.ac.uk/id/eprint/5179 for details of how to contact us. 
The ethics of and the appropriate legislation concerning killing people and letting them die: a response to Merkel.

\author{
Hugh V McLachlan
}

\title{
Emeritus Professor of Applied Philosophy \\ Glasgow Caledonian University
}




\begin{abstract}
With regard to ethics and legislation, what is the significant difference between a doctor terminating the life supporting treatment of a patient in the course of his job and a greedy relative of the patient doing the same thing to inherit his wealth? Merkel offers an interesting and inventive answer to this question in terms of the improper violation of personal boundaries. However, despite Merkel's claim to the contrary, his answer does not directly address the question of the relevant ethical similarities and differences between killing and letting die in general. Furthermore, it does not provide the basis a plausible rationale for legislation concerning killing and letting die. The questions of whether letting someone die is ethically the same as killing someone and whether it should be treated the same way by the criminal law are not the same as or tantamount to the question of whether or not it involves the transgression of another person's boundaries.
\end{abstract}

Keywords: euthanasia, killing, care of dying patient, criminal law. 


\section{INTRODUCTION}

Merkel raises the general questions of whether, when and why killing and letting die are morally the same thing and should be treated identically by the law.[1] By way of exposition of his proposed answers, he addresses the specific questions of the nature and moral status of the switching off by his or her doctor and by his or her nephew of a patient's life support system. Merkel argues that if, in the course of his work in a hospital, a doctor switches off the life support machine of one of his patients, it does not constitute the killing of his patient whereas, if a greedy nephew does so in order to receive an inheritance from him or her, it does. Even if Merkel is correct in his answers and analysis and he has offered an acceptable solution to "the standard textbook problem whether actively shutting off a life-sustaining medical device, e.g. a respirator, and thus bringing about a patient's death amounts to active killing or just to an omission of further treatment', he has not thereby necessarily correctly answered the general questions about killing and letting die that are referred to in the first sentence of this paragraph. [2] His proposed answers to these general questions are not plausible.

There might or might not be a significant moral difference between a doctor killing a patient by, say, smashing his skull with a hammer and letting him die by failing to continue to provide life sustaining treatment for him. There might or might not be a significant moral difference between a greedy cousin's killing his uncle by smashing his head with a hammer and letting him die by halting the provision of the life sustaining treatment that his doctor was providing for him. However, it is not clear what issue is illuminated and what question is answered by comparing the doctor's failure to continue the provision of the treatment with the nephew's termination of it. To make this particular comparison is not to focus fully or directly upon the 'killing or letting die' question. $[3,4,5]$

\section{KILLING AND LETTING DIE: MERKEL'S ANALYSIS}

Merkel considers that:

'What is decisive for the question whether switching off a respirator and thereby bringing about a patient's death is a form of active killing is not the obvious fact that the switching-off is an activity; nor is it that this action (arguably) is causal for the ensuing death. Rather, what's decisive is whether it amounts to transgressing the boundaries of the victim's own domain by positively causing harmful effects.' [6]

In this light, the suggested wrongfulness of a third party in switching off such a machine is contrasted with the suggested legitimate behaviour in so doing of the patient's doctor. Merkel writes:

'What such a person does is to actively make his or her own sphere hermetic so that no more helpful effects originating from within - that is, the respiratory air effusing from the machine - can cross those boundaries to the benefit of someone outside: a case of actively organising one's omission. In contrast, any third party who switches the 
respirator off intervenes in a life-sustaining causal circuit set up by others, hence transgresses the bounds of their own domain by transferring harmful effects into that of another: a clear case of active killing.' [6]

In addition to the switching off of a respirator, Merkel also considers examples such as where death for a particular vagrant follows the withdrawal of an application of heating and the death of particular plants follows the ending of a process of irrigation. $\mathrm{He}$ considers that his analysis reveals a pattern.

'A closer look at our cases reveals their common structure. First, someone actively seals up, as it were, from within the borders of a domain legally assigned to his or her authority, so as to block any potentially auxiliary effects from leaving that domain to the benefit of others. Second, there is no legal obligation to grant such helpful effects. Third, in actively blocking them the agent brings about harmful consequences outside his or her own domain.' [7]

Merkel's analysis of the switching off of the life support machine is based on the view that 'There is a normative asymmetry between doing and allowing, irrespective of the parity or even identity of consequences ensuing from either. At least that's what the law says.'[8]

With regard to this supposed moral asymmetry between doing and allowing, He writes:

'The asymmetry evidently manifests itself in the aforesaid diverging liabilities for doing and allowing. Example: A pushes 5-year old X into a pond in order to kill him. If the child drowns, $\mathrm{A}$ is responsible for committing murder. B passing by the scene does not save X though he easily could. He is not responsible for the child's death but only for failure to assist a person in danger, a comparatively trivial criminal offense. If, however, the passive bystander is X's father F, the normative asymmetry between doing and allowing shrinks to a minimum. $\mathrm{F}$ is responsible for the child's death and liable for murder by omission.'[8]

\section{PROBLEMS WITH MERKEL'S ANALYSIS}

\section{Causation, responsibility, blameworthiness, culpability and accountability}

The relationships between causation, culpability and 'responsibility', are more complex than Merkel's analysis seems to allow. We can bear a moral and/or a legal responsibility for a death that we did not cause and for a killing that we did not commit. We can be legally responsible for an action which occurred that we did not commit and for which we bear little or no moral responsibility as, for instance, in some applications of the law of common purpose. Similarly, we are not always morally or legally responsible for what we do cause. If, say, we fall from a cliff and kill someone below when we land or someone who is attached to us by a rope and who shares our fall, we cause a death that 
we might not be morally or legally responsible for. [9] A boxer might kill an opponent in the course of a bout - he might do so intentionally even if unexpectedly - yet have no legal responsibility for killing his opponent or for his death. However, if the fight and the death occurred outside the ring - at the weigh-in, perhaps - the surviving boxer would face a charge and a likely conviction for manslaughter or murder. The nature and the extent of the moral responsibility and the culpability borne in both instances by the victorious boxer is an interesting matter of debate.

It is wrong to push someone off a cliff and thereby to kill him. It could be seen as: '...transgressing the boundaries of the victim's own domain by positively causing harmful effects.' [6] However, suppose that we meet someone on a walk in the mountains who asks us the route to the local hotel. Suppose that we deliberately give misinformation and direct the person along a path that leads to a very steep and precipitous cliff. Suppose that, as we expected might happen, the stranger subsequently and consequently falls to his death. Our behavior would not be describable as: '... transgressing the boundaries of the victim's own domain by positively causing harmful effects'.[6] Nonetheless, to thereby let the person die might be considered to be morally as bad as murder. It would be a death for which we had considerable moral and possibly some legal responsibility. The law might treat it as seriously as some murders. We would be blameworthy and deserving of punishment. On the other hand, suppose that sincerely, conscientiously and honestly we mistakenly give this misinformation. The physical causation remains the same. The harm remains the same. There is no more or less crossing of the boundaries of the individual people involved in the situation. However, with regard to 'responsibility', moral wrongfulness and legal culpability, the instances are vastly different.

Suppose that we were to stand by and watch someone walking towards and then over a very high and steep cliff when we could have easily and safely constrained him or, at least, have warned him of the danger. To stand by in this fashion is not to intrude into the protected domain of another. However, it is to let someone die. In some jurisdictions, it might be a crime. It might be a breach of a legal duty of care towards other people. In all times and places and jurisdictions it would surely be morally wrong to fail to try ensure that the person was aware of the danger of falling over the cliff if we readily and safely could. We would bear a moral and, possibly, a legal responsibility not because of what we caused but because of what we failed to do and failed to prevent.

If we knew that the person was aware of the cliff and intended to commit suicide, it is not clear whether and to what extent we should try to prevent him from doing so. It all depends. In some circumstances, it would be morally obligatory, in some circumstances, it would be morally permissible and in other circumstances, it would be morally laudable although not obligatory.

Suppose that a patient's life-support machine had been inadvertently switched off. Suppose that, when walking past, a doctor who was professionally responsible for this particular patient's care noticed that the machine was unplugged. If she failed to reconnect the machine or take steps to ensure that the machine was reconnected by some other responsible person, she is thereby consciously letting the patient die. She is, one 
might say, deliberately failing to prevent the patient's being killed in a particular predictable way. However, she is not thereby '... transgressing the boundaries of the victim's own domain by positively causing harmful effects'. [6] Nonetheless, the inaction would be highly immoral. It should be a crime - such as, say, homicide by negligence - in all jurisdictions.

There would be a difference in the moral and legal status of the behaviour if someone other than the patient's doctor failed to reconnect the machine but not a difference of the sort that Merkel suggests. In both instances, they do the same thing - they fail to recommence a process that is necessary but not sufficient to keep someone alive: they let him die. Suppose that someone who is not a doctor passes by the same scene with the same knowledge of the effect on the patient if his life support system is not re-connected to him. If he fails to reconnect the machine and thereby lets the doctor's patient die it is not clear that he bears any responsibility for the patient's death. The passerby should, perhaps, shout 'Help' and summon assistance. That, surely, would discharge any moral duty of care that he has for the person. Failure to do so might be morally wrong but it would be not be, like the behavior of the doctor, heinous. It would be excusable. When we are placed in extreme and unusual circumstances, we do not always think quickly or clearly. Failure to reconnect the machine or summon aid would hardly lead to a trial for breach of a legal duty far less to a safe conviction. If the passerby were to reconnect the machine, he is more likely to be praised for his presence of mind and altruistic behaviour rather than to be thought to have merely done what was morally or legally required of him.

Suppose that it happened to be the greedy nephew who passed by and that his rich uncle was the dying patient. His behavior, like that of the doctor would, I think, be correctly describable as letting the person die. The fact that he wants his uncle to die does not make him any more morally or legally responsible for his uncle's death than the passerby who is unrelated to him and does not long for his death. On the other hand, if, while standing to gain a lot of money when his uncle dies, the greedy nephew intervenes in the causal process between the patient and his professional medical practitioners and saves his uncle's life by reconnecting the machine, we might well deem his action to be morally praiseworthy, even more so than the same action would be if it were performed by a disinterested passerby.

\section{Supposed moral asymmetry and the moral duty of care}

Merkel says that there is a moral asymmetry between doing and allowing. I would suggest that, on the contrary, the moral duty in some circumstance not to kill someone and the moral duty in some circumstances (to let or) not to let someone die might be thought both derive from a general vaguely defined moral duty of care towards and concerning other people. In any event, the relationship between killing and letting die is more complex and varied than Merkel's scheme suggests. To kill and to let die are not morally identical. They pertain to the potential performance and breach of different moral duties. Sometimes, to let die is not morally wrong when to kill would be morally wrong. 
For instance, it would be morally wrong for a prison guard to kill a prisoner who was on hunger strike but morally right to refrain from force-feeding him and thereby let him die. Sometimes, to let die would be morally worse than to kill.

In Merkel's example of the drowning of a child, I would say that B and F both bear a moral responsibility for the death of the child although not for killing him. Their behaviour is morally blameworthy because it is the breach of a duty of care towards the child. F's behaviour is morally worse than that of B because he has a heavier duty of care than B towards the child. The father's behaviour might be thought on these grounds to be even morally worse than the behaviour of A, who is morally and legally responsible and culpable for the murder of the child. Whether or not B and F are guilty of crimes - and what these crimes are called - depends on the political choices that have been made within that jurisdiction. In most or all jurisdictions, some, but not all, failures to save some people are crimes. The failure of the father to save his child in these particular circumstances might be in some jurisdictions a crime that is punished as severely as murder is punished whatever the particular crime is called - 'unlawful killing by parental neglect' or such like.

Although we have a moral duty of care towards our fellow human beings, it is a matter of contention what is required of us in order to discharge that duty. For instance, even if there were a moral duty to sacrifice, say, £10 if it would save the life of a stranger, to sacrifice, say, $£ 10,000$ to save a stranger's life would be a magnanimously charitable act. When does a form of action change from a moral requirement to a type of supererogatory, morally praiseworthy behaviour? There is no obvious short correct answer. Sometimes, in some circumstances, some people will be morally required or even legally required to do more to promote the health and continued existence of some other people than to refrain from wantonly killing them. However, to refrain from killing other people wantonly might, at least in some circumstances be sufficient for some people to discharge their moral duty of care towards some or even all other people. To do more for their comfort, happiness and security might be morally permissible and laudatory but not morally obligatory.

To kill other people wantonly is always a breach of our moral duty of care. However, it is not always a breach of this duty to kill other people. For instance, they might threaten the lives of other innocent people. To fail to kill them might be to let other innocent people die. It might be better and more in accord with our duty of care towards our fellow human beings to kill a terrorist than to let his hostages be killed by him. Similarly, it might be in accord with our duty of care to kill someone who pleads for death and is unable to kill himself painlessly and quickly. To let such a person die painfully and slowly might be a breach of our moral duty of care even if it is, in some jurisdictions, the criminal offence of murder to fulfil it. To shoot a fatally wounded foe or comrade who is writhing in his last hours of torment on the battlefield might, in some circumstances, be a moral duty whatever the law might happen to say. 
We can have moral duties concerning killing and letting die that are not derivable - or not derivable in an obvious or straightforward way - from a duty of care to our fellow human beings. Suppose that we were spectators at the execution of a convicted, confessing but unrepentant serial rapist and murderer. Although it would be wrong for us to usurp the role of the executioner and kill the murderer ourselves, it is plausible to suggest that we should let him die. To try to physically intervene and prevent the execution would be morally wrong or so we might argue. It would also be illegal. Whether or not it would be morally appropriate to try to prevent the execution legally by way of persuasion, petition and appeal is a matter of dispute. The ethics of capital punishment is, clearly, a debatable issue. However, the ethics of capital punishment does not revolve around a dispute about whether or not it causes harm by improperly penetrating the barrier wall of another person. It is more about what the strengths and contents of our various - often competing - moral duties are.

\section{CONCLUSION}

With regard to Merkel's example of the switching off of a life support machine, I am not convinced that he is correct to say: 'The nephew commits an active killing by switching off the respirator whereas the doctor doing the exact same thing only omits something, namely to keep the patient alive'. [10] Nonetheless, even if he is correct with regard to this specific issue, his analysis does not correctly answer the central questions of the general issue of the ethics of and the appropriate legislation concerning killing and letting die. The questions of whether letting someone die is ethically the same as killing someone and whether it should be treated the same way by the criminal law are not the same as or tantamount to the question of whether or not it involves the transgression of another person's boundaries. Although, as he notes, his analysis does not accord with how criminal courts of law actually do operate in cases of and like the switching off of respirators with regard, say, to euthanasia, he thinks that they should. He presents, he suggests a 'paradigm of a coherent and well-reasoned' argument for that purpose. [6] The suggestion is implausible.

\section{REFERENCES}

1 Merkel R. 'Killing or letting die? Proposal of a (somewhat) new answer to a perennial question. J Med Ethics 2016;42:353-360.

2 Merkel R. 'Killing or letting die? Proposal of a (somewhat) new answer to a perennial question. J Med Ethics 2016;42:353 (abstract).

3 McLachlan HV. The Ethics of Killing and Letting Die: Active and Passive Euthanasia. J Med Ethics 2008;34:636-638. 
4 McLachlan HV. To kill is not the same as to let die: a reply to Coggon. Journal of Medical Ethics 2009;35:456-458.

5 McLachlan HV. Assisted suicide and the killing of people? Maybe. Physician-assisted suicide and the killing of patients? No: the rejection of Shaw's new perspective on euthanasia. J Med Ethics 2010;36:306-309.

6 Merkel R. 'Killing or letting die? Proposal of a (somewhat) new answer to a perennial question. J Med Ethics 2016;360.

7 Merkel R. 'Killing or letting die? Proposal of a (somewhat) new answer to a perennial question. J Med Ethics 2016;355.

8 Merkel R. 'Killing or letting die? Proposal of a (somewhat) new answer to a perennial question. J Med Ethics 2016;354.

9 Persson I, Savulescu, J. Unfit for the Future: The Need for Moral Enhancement. Oxford:Oxford University Press, 2012:60-66.

10 Merkel R. 'Killing or letting die? Proposal of a (somewhat) new answer to a perennial question. J Med Ethics 2016;42:353. 